Fellows and Licentiates of the College of has been tried. No success attended any Physicians, where would be the field for enulation? Of what use would be sycophancy and subserviency, if a fellowship or a commissionership were not occasionally to reward the professor of those noble sciences ?" But how are a high level, and one uniform denomination, to destroy emulation? The Fellows of the College hi ve the same level and rank; so have the Licentiates. Has this level destroyed anbition and emulation among them? Has no Fed ow risen above his level in the grade? Has Elliotson's emulation been crushed by being in the high level of his class? Has no Licentiate risen by talent and emulation above his level? Is there no licentiate, friend Green, who has got above yourself, in the estimation of his professional brethren, or society at large? Is it possible that a journalist, who is the organ (I will not use the vulgar expression which you apply to a contemporary) of the medical aristocracy or oligarchy, should be so defective of common sense and common reason, as to maintain that a high level of medical education, or of any education, would tend to "destroy emulation?" It would have precisely the opposite effect. As distinction could then result only from superiority of knowledge and talent, and could not be purchased by interest or sycophancy, the real and effectual stimulus to exertion would be constantly supplied, and talent would, still more surely than at present, attain its level, - far above the general level, however high that might have been fixed. So much for the two points now discussed. I shall pay my respects to you, friend Green, whenever your lucubrations attract the attention of your devoted servant,

London, Jan. 2, 1834.

Gracchus.

\title{
PROPAGATION OF LEECHES.
}

\section{To the Editor of Trre L.1NCET.}

Sir,-On perusing the interesting account regarding leeches, in your Journal of this day, I thought the following extract from a lecture on leeches, delivered by me at the Westminster Dispensary, night be useful. Yours truly, JOHN EPPS, M.D.

89, Grent Russcll-strcet, Dec. 28.

"Leeches, gentlemen, being thus valuable as medicinal agents, it has always been a matter of inquiry, What is the best mode of keeping leeches so that they may PRopAGATE?" A great variety of means plan but one that was devised by the phy. sician-general to the forces in one of onr West India islands (I forget the gentle. man's name). IIe took clay, and having worked it well, placed it in the centre of a large vessel in which he kept leeches. He found in a short time that the leeches burrowed holes in this clay, so as to give it a perforated appearance; and, much to his delight, observed young leeches to appear after a short time. After this, this gentletleman found no difficulty in obtaining any supply of leeches."

This extract strikingly corroborates one remark of Mr. Sherriff's, namely, that the earth, which he recommends to be put in the box, will answer better if it be of a clayey nature. And I have very little doubt that if he watches with care he will observe ova at the proper season.

J. E.

\section{CORRESPONDENTS.}

On handing the letter of Dr. Fergusson to our reporter, that gentleman states " that he did not consider Dr. Fergusson to have been acting in hostility to the eighth resolution, and did not by any means intend to employ the term 'warmth' invidiously. With regard to the word 'trimmph, all that was meant in the report was, that Dr. Copland succeeded nltimately in bringing the meeting to act in conformity with his first decision." - At the request of Dr. Fergusson, the letter of Dr. F, is withheld from publication.

Notick.-Dr, Epps has in the press an account of a case of epilepsy, which was cured after the disease had existed twenty years.

G. J. P.-In reply to questions 3,4 , and

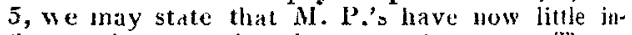
llutuce in procurinc those appointments. The regolations are too long $t o$ insert in this place, bnt if onr conespondunt will call at the oflices of the Army and Navy Boards, he may ubtain copies of them.

The enigma from Aylesbury or Woodbridge is unintelligible to us.

Ein Naturversíandiger. - We have seathed omr list, and cannot tind a single insance of early or late lectures un anatomy. Half-past two is the usllal honr.

A Pupil should ask Dr. R. himself.

Preparing for publication " The Study of Belewhery, or llistany of the bones of the $\mathrm{Hit}$.

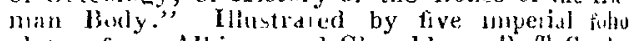
plales, fromin Alhinms and Cheselden. By T. Cdetle, F.L.S. Lin. Coll. Camb. dec.

Earatur.--In leader, last weck, page rith, lime 13, transpose one of the "and's" to the end of the line. 